\title{
Quantitation of Helicobacter pylori in dental plaque samples by competitive polymerase chain reaction
}

\author{
Q Song, B Haller, D Ulrich, A Wichelhaus, G Adler, G Bode
}

\begin{abstract}
Aim-To establish a competitive PCR (cPCR) assay for quantitation of $H$ pylori organisms in dental plaque samples. Methods-The cPCR coamplified target $H$ pylori DNA and a known amount of internal standard template in the same tube with the same primers directed to $0.86 \mathrm{~kb}$ DNA of $H$ pylori. The internal standard was a synthesised DNA bearing the same primer recognition sites at two ends and a non-homologous core sequence as the target DNA fragment. Quantitation was based on determination of the relative, not absolute, amounts of the differently sized and $\left[{ }^{32} \mathbf{P}\right]-d C T P$ labelled products derived from $H$ pylori DNA and the competitive internal standard after gel electrophoresis separation.
\end{abstract}

Results-A significant correlation between known amounts of $\boldsymbol{H}$ pylori added to dental plaque samples and the results of the cPCR was found, and a standard line was developed which allowed quantitation of $H$ pylori in the plaque samples. CPCR was performed on supragingival plaque samples from 10 adult patients with $H$ pylori infection in the stomach, and from five adults and six children without $H$ pylori infection in the stomach. The ranges of $H$ pylori numbers were 1-213 (median 25), 6-76 (10), and 4-94 (14) cells/mg of dental plaque in the three groups, respectively.

Conclusions-cPCR is useful for quantitation of $H$ pylori in supragingival dental plaque samples; however, the number of the organisms in dental plaque samples seems very low.

(F Clin Pathol 2000;53:218-222)

Keywords: Helicobacter pylori; competitive PCR; dental plaque

There is an increasing body of evidence that $H$ pylori DNA may often be identified in samples from dental plaque of patients with and without $H$ pylori infection in their stomachs. ${ }^{1-8}$ Discrepant results concerning the prevalence of $H$ pylori in the oral cavity may be caused by different methods or different study populations. Nevertheless, a quantitative analysis of $H$ pylori organisms in oral samples might be useful because of its high sensitivity and specificity compared with other diagnostic methods, which require relatively large numbers of bacteria to obtain positive results. ${ }^{9-12}$

Several quantitative PCR assay methods have been reported. Competitive PCR (cPCR) is appropriate for the quantitation of small amounts of the target sequence because there is no need to restrict the number of amplification cycles, and this increases the sensitivity of the assay. ${ }^{13}$ This method has proved useful in quantitating mRNA and DNA of microorganisms, ${ }^{14-18}$ including $\mathrm{H}$ pylori in gastric mucus. ${ }^{19}$ cPCR coamplifies two different templates bearing the same primer recognition sequences in the same tube. Therefore any variable influencing the amplification reaction should affect both templates similarly, and the relative abundance of coamplified products should remain constant even under different conditions of amplification efficiency. The ratio of PCR products is related to the initial template concentration. Among the two templates, one is a competitive internal standard of known concentration and the other is a target sequence of unknown amount. Therefore the initial quantity of the target sequence can readily be determined from a known amount of internal standard. ${ }^{1320}$

Our aim in this study was to establish a cPCR assay for quantitating the numbers of $H$ pylori organisms in dental plaque samples.

\section{Methods}

SUBJECTS AND SAMPLES

Dental plaque samples from supragingival location used in this study were collected by dentists from symptomatic adult patients who underwent gastroduodenoscopy in the University Clinic of Ulm and from children under orthodontic treatment in the Department of Orthodontics, University of Ulm. Informed consent from the patients or from the parents of the children was obtained in each case. The study was approved by the ethics board of the University of Ulm. Before endoscopy and before incorporation of an orthodontic device, dental plaque samples were scraped from different locations and transferred into tubes containing sterile physiological saline. The curettes used in this study are sterilised and washed thoroughly before autoclaving. It has been shown by Roosendaal et al that false positive PCR results can be obtained by contaminated instruments used for collecting samples. $^{21}$

Dental plaque was weighed and stored immediately at $-20^{\circ} \mathrm{C}$ until DNA extraction. Active infection with $H$ pylori was determined by the ${ }^{13} \mathrm{C}$-urea breath test (UBT) in each case. ${ }^{22}$ Patients who had taken drugs such as antibiotics, proton pump inhibitors, $\mathrm{H}_{2}$ blockers, antacids, and bismuth compounds within the last three months were excluded. These drugs are known to interfere with the urea breath test, leading to a false negative result. 
DNA PREPARATION FOR PCR

In order to avoid false positive results in the nested PCR owing to contamination in the laboratory, great care was taken at all steps in the preparation of the samples; thus we used fresh disposable devices, prepared template DNA, pre-PCR, and post-PCR materials in separate places, changed gloves frequently, and applied other measures outlined by Kwork and Higuchi. ${ }^{23}$

DNA extraction from dental plaque samples was as described by Li et al. ${ }^{4}$ Briefly, the dental plaque samples were vortexed thoroughly and washed with physiological saline. The pellets were suspended in digestion buffer $(0.1 \mathrm{M}$ $\mathrm{NaCl} / 0.01 \mathrm{M}$ Tris $\mathrm{HCl}[\mathrm{pH}$ 8.3] / $0.25 \mathrm{M}$ EDTA / 1\% sodium lauryl sarcosine) containing proteinase $\mathrm{K}$ (final concentration 100 $\mu \mathrm{g} / \mathrm{ml}$ ), and incubated at $55^{\circ} \mathrm{C}$ for three hours. DNA was extracted with phenol-chloroform, precipitated with isopropanol, and washed with $70 \%$ ethanol. Each DNA pellet was resuspended in $150 \mu \mathrm{l}$ of sterile water. The DNA samples were then investigated for the presence of $H$ pylor $i$ DNA by nested PCR using primers EHC-U/EHC-L (5'-CCCTCACGCCATCA GTCCCAAAAA3'/5'-AAGAAGTCAAAAAC GCCCCAAAAC-3') ${ }^{4}$ and ET-5U/ET-5L (5'GGCAAATCATAAGTCCG CAGAA-3'/5'-T GAGACTTTCCTAGAAGCGGTGTT-3'; courtesy of Li C, East Tennessee State University, USA), which were directed to an 860 base pair (bp) fragment of $H$ pylori DNA. The region targeted by the primers EHC-U/ EHC-L is located in $80076-80492$ bp of the genome of $H$ pylori ${ }^{24}$.

The primer set ET-5U/ET-5L, which is internal to the fragment amplified by EHC-U/ EHC-L, had an expected product size of 230 bp (corresponding nucleotides, 446 to 675 of the 860 bp DNA of $H$ pylori; Thomas E, Li C, East Tennessee State University, Johnson city USA; personal communication).

The samples that were $H$ pylori DNA positive by the nested PCR were further investigated by quantitative cPCR.

COMPETITIVE PCR

cPCR was performed as described by Gilliland et $a l$ and Sambrook et al. ${ }^{1320}$ The primer set used was EHC-U/EHC-L. The competitive internal standard was a synthesised single strand DNA (140 bases) containing the same primer recognition sites at the two ends, and a non-homologous core sequence as the target $417 \mathrm{bp}$ fragment. The internal standard and the target $417 \mathrm{bp}$ fragment have similar $\mathrm{G}+\mathrm{C}$ compositions (38.6\% and $36.2 \%$, respectively) based on the sequence of the $417 \mathrm{bp}$ fragment (Thomas E, East Tennessee State University, USA; personal communication). Precise 10fold serial dilutions of internal standard, ranging from $10^{\circ}$ to $10^{-9} \mathrm{pg} / \mu \mathrm{l}$, were prepared in a relatively large volume $(1 \mathrm{ml})$ so that the same dilution series could be used for multiple concentration determinations. For PCR amplification, six identical portions of DNA suspension of each sample were added into six parallel reactions, each of which contained decreasing known amounts of internal standard. Each reaction was performed in a $25 \mu \mathrm{l}$ volume, containing $2.5 \mu \mathrm{l}$ of $10 \times \mathrm{PCR}$ buffer $(100 \mathrm{mM}$ Tris $\mathrm{HCl}[\mathrm{pH} 9.2] / 15 \mathrm{mM} \mathrm{MgCl}_{2} / 750 \mathrm{mM} \mathrm{KCl}$ ), $0.5 \mu \mathrm{l}$ of $10 \mathrm{mM}$ dNTPs (final concentration $0.2 \mathrm{M}), 25 \mathrm{pM}$ of each primer, $5 \mu \mathrm{l}$ of dental plaque DNA, $2.5 \mu \mathrm{l}$ of internal standard DNA, $1.25 \mathrm{U}$ of Taq polymerase, and $0.125 \mu \mathrm{l}$ of ${ }^{32} \mathrm{P}-$ $\alpha$-dCTP (final concentration, $50 \mu \mathrm{Ci} / \mathrm{ml}$ ). Each tube was overlaid with $25 \mu \mathrm{l}$ of mineral oil. The amplification consisted of the initial denaturation at $95^{\circ} \mathrm{C}$ for five minutes, 40 cycles with denaturation at $94^{\circ} \mathrm{C}$ for 45 seconds, annealing at $59^{\circ} \mathrm{C}$ for 30 seconds, extension at $72^{\circ} \mathrm{C}$ for 45 seconds, and the last extension at $72^{\circ} \mathrm{C}$ for 10 minutes. A negative control (without target DNA and internal standard) was used to monitor false positivity and to determine the background of radioactivity.

After amplification, $10 \mu \mathrm{l}$ aliquots of PCR products were analysed by electrophoresis on $2 \%$ agarose gels containing ethidium bromide. The 417 bp bands ( $H$ pylori DNA) and the 140 bp bands (internal standard DNA) were excised from the gels and the amounts of radioactivity counted in a scintillation counter. The radioactivity of the $140 \mathrm{bp}$ band was multiplied by ratio of $\mathrm{G}+\mathrm{C}$ in the $417 \mathrm{bp}$ fragment to that in the $140 \mathrm{bp}$ fragment to correct for increased label per mol by the larger fragment. The point of equivalence, where yield of target fragment equalled that of internal standard, reflected equal starting amounts of target $H$ pylori DNA and internal standard DNA (fig 1).

DEVELOPMENT OF STANDARD LINE

First, a suspension of cultivated clinical isolates of $H$ pylori was prepared and the number of $H$ pylori cells determined with a Thoma chamber. Aliquots were diluted to concentrations of $10^{6}, 10^{5}, 10^{4}, 10^{3}, 10^{2}, 10^{1}$, and $10^{\circ} \mathrm{H}$ pylori cells $/ \mu$ with $H$ pylori negative dental plaque suspension.

Dental plaque samples with negative PCR result for $H$ pylori DNA were only detected in patients who had recently been treated with anti- $H$ pylori triple therapy, or who had received antibiotic treatment for other reasons. The pooled dental plaque from these subjects was used for the dilution experiments and for the construction of the standard line.

DNA was then prepared from these mixtures using the method described above. Finally, the quantity of $H$ pylor $i$ in each mixture was determined at least twice by the cPCR method. The correlation coefficient $r$ was calculated for the association between the actual quantity of $H$ pylori in the suspensions and the results of the cPCR assay. The statistical significance of the $r$ value was assessed, and the regression line and equation were established. This relation was used as the standard for quantitation of $H$ pylori in the dental plaque samples.

\section{Results}

Ten H pylori positive adult patients (six women, four men; mean age 49.1 years), five $H$ pylori negative adult patients (one women, four men; mean age 46.8 years), and six $H$ pylori negative children (four girls, two boys; mean age 11 years) were selected to evaluate 
A

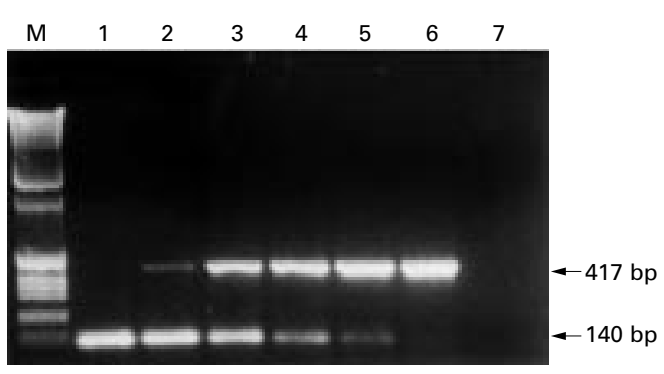

B

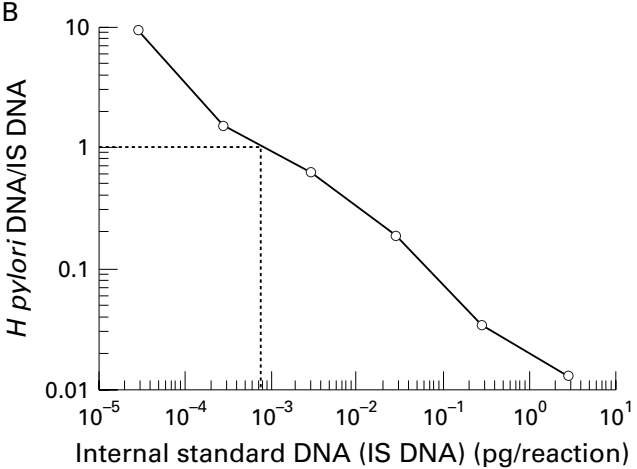

Figure 1 Competitive polymerase chain reaction (cPCR) quantitation of $H$ pylori. (A) Each PCR reaction contained primers EHC-U/EHC-L, radiolabelled dCTP, a different amount of internal standard DNA (IS DNA), and a fixed amount of DNA extracted from a mixture of $H$ pylori and dental plaque. Lane $M, 1 \mathrm{~kb} D N A$ ladder; lanes 1 to $6,2.5,2.5$ $\times 10^{-1}, 2.5 \times 10^{-2}, 2.5 \times 10^{-3}, 2.5 \times 10^{-4}$, and $2.5 \times 10^{-5} \mathrm{pg}$ of the internal standard $D N A$, respectively; lane 7 , negative control. (B) Data were plotted as log of the ratio of $H$ pylori DNA/internal standard DNA v log internal standard DNA. The point of equivalence (ratio $=1$ ) reflects equal starting amount of $H$ pylori DNA and internal standard DNA.

the quantitative cPCR method. The demographic data of the patients are shown in table 1. The mean (SD) amount of plaque sample analysed per subject in $H$ pylori positive adults was 22.2 (10.8) $\mathrm{mg}$, in $H$ pylori negative adults 20.4 (6.7) $\mathrm{mg}$, and in $H$ pylori negative children 12.8 (5.3) $\mathrm{mg}$.

STANDARD LINE AND REGRESSION EQUATION

The standard line is shown in fig 2. A significant correlation $(r=0.998, \mathrm{p}<0.001)$ was found between the known amounts of $H$ pylori and the results of the cPCR assay. The relation was expressed as a regression equation: $\mathrm{Y}=3 \times 10^{-9} \mathrm{X}$. $\mathrm{Y}$ is the result of the $\mathrm{CPCR}$ assay (pg), and $\mathrm{X}$ is the amount of $H$ pylori DNA (number of organisms) in each PCR reaction.

NUMBER OF H PYLORI ORGANISMS IN DENTAL PLAQUE SAMPLES

Table 1 shows the number of $H$ pylori organisms per mg of dental plaque sample. Adult patients with active $H$ pylor $i$ infection showed a

Table 1 Demographic data of patients $(n=21)$ and results of quantitative $\mathrm{CPCR}$

\begin{tabular}{|c|c|c|c|c|c|}
\hline Patient & $\begin{array}{l}\text { Age } \\
\text { (years) }\end{array}$ & Sex & Diagnosis & $\begin{array}{l}\text { H pylori } \\
\text { status in } \\
\text { stomach }^{*}\end{array}$ & $\begin{array}{l}\text { H pylori cell } \\
\text { No/mg dental } \\
\text { plaque }\end{array}$ \\
\hline 1 & 23 & $\mathrm{~F}$ & G†, DU & + & 171 \\
\hline 2 & 32 & $\mathrm{~F}$ & G & + & 11 \\
\hline 3 & 48 & $\mathrm{~F}$ & $\begin{array}{l}\text { G, Crohn's } \\
\text { disease }\end{array}$ & + & 25 \\
\hline 4 & 55 & $M$ & G & + & 53 \\
\hline 5 & 60 & $\mathrm{~F}$ & $\begin{array}{l}\text { G, hiatus } \\
\text { hernia }\end{array}$ & + & 1 \\
\hline 6 & 70 & M & G & + & 25 \\
\hline 7 & 42 & $M$ & $\mathrm{G}, \mathrm{DU}$ & + & 3 \\
\hline 8 & 58 & $\mathrm{~F}$ & $\begin{array}{l}\mathrm{G} \text {, hiatus } \\
\text { hernia }\end{array}$ & + & 30 \\
\hline 9 & 70 & $\mathrm{~F}$ & G & + & 3 \\
\hline 10 & 33 & $M$ & G & + & 213 \\
\hline 11 & 26 & $M$ & Oesophagitis & - & 6 \\
\hline 12 & 49 & $M$ & Oesophagitis & - & 76 \\
\hline 13 & 64 & $M$ & $\mathrm{~N}$ & - & 16 \\
\hline 14 & 57 & $\mathrm{~F}$ & $\mathrm{~N}$ & - & 10 \\
\hline 15 & 38 & M & $\begin{array}{l}\text { Hiatus } \\
\text { hernia }\end{array}$ & - & 7 \\
\hline 16 & 12 & $M$ & 19 & - & 16 \\
\hline 17 & 11 & $\mathrm{~F}$ & 1 & - & 4 \\
\hline 18 & 10 & $\mathrm{~F}$ & 1 & - & 10 \\
\hline 19 & 13 & $\mathrm{~F}$ & 1 & - & 15 \\
\hline 20 & 10 & $\mathrm{~F}$ & 1 & - & 94 \\
\hline 21 & 10 & M & 1 & - & 12 \\
\hline
\end{tabular}

${ }^{\star}$ Result of the ${ }^{13} \mathrm{C}$-urea breath test; †gastritis; $\ddagger$ duodenal ulcer; §normal; $\lceil$ not done. range from 1 to $213 H$ pylori organisms (median 25), adult patients without $H$ pylori infection showed a range from 6 to $76 \mathrm{H}$ pylori organisms (median 10). In children without $H$ pylori infection, $H$ pylori amount varied from 4 to 94 organisms (median 14). In most samples $(79 \%)$, less than $50 \mathrm{H}$ pylori organisms were found in $1 \mathrm{mg}$ of dental plaque.

\section{Discussion}

To our knowledge, this is the first report to quantify $H$ pylori in supragingival dental plaque samples, and the results show very few $H$ pylori organisms. The small number of $H$ pylori organisms, the presence of coccoid forms of $H$ pylori (probably caused by the increased oxygen environment of supragingival plaques), and the presence of numerous other microorganisms may have contributed to the failure to cultivate the bacterium from the oral cavity in previous studies. ${ }^{9-12}$ Such low numbers of $H$ pylori in dental plaque may also be responsible for the reported variation of PCR detection of $H$ pylori in oral samples. ${ }^{13} 10112526$ The PCR detection limit of $H$ pylori is usually about 5-100 cells. ${ }^{46-30}$ The number of $H$ pylori in $1 \mathrm{mg}$ of dental plaque is similar using the PCR detection limit; thus a small change of the

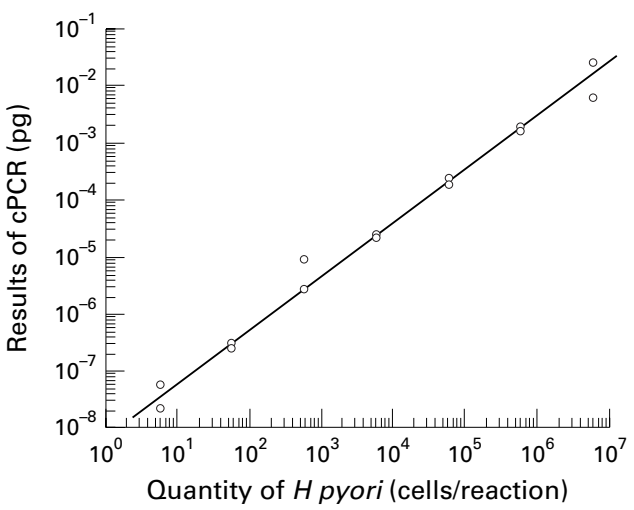

Figure 2 Results of competitive polymerase chain reaction (cPCR) quantitation of a known amount of $H$ pylori added to dental plaque. These results of this assay correlate significantly with the actual $H$ pylori amounts $(r=0.998$, $p<0.001)$. The regression line is expressed as: $Y=3$ $\times 10^{-9} X(Y=$ result of $c P C R$ assay; $X=$ number of H pylori). 
detection limit will lead to very different results. However, the primers EHC-U/EHC-L and the $860 \mathrm{bp}$ fragment were shown to be very specific and sensitive for $H$ pylori DNA by $\mathrm{Li}$ et $a l,{ }^{40}$ and also by us in a previous report. ${ }^{31}$ Furthermore, we were able to show a high degree of homology, with more than $97 \%$ nucleotide identity when comparing the sequence of the 230 bp products of $H$ pylori type strain ATCC 43629 with 39 oral samples from 20 patients (Song Q, et al, unpublished data).

Using a synthesised single strand DNA as internal standard, we found a significant correlation between the known amount of $\mathrm{H}$ pylori added to dental plaque and the result given by cPCR. Furuta et al obtained similar results using a synthesised single strand DNA as internal standard. ${ }^{19}$ Their results of quantitating $H$ pylori in gastric mucus were significantly correlated with those of other methods. Therefore, synthesised DNA can be used as an internal standard in CPCR quantitation of $H$ pylori. On the basis of our experience, the following conditions are necessary to overcome problems during quantitation of $H$ pylor $i$ in dental plaque samples with cPCR:

- the use of highly specific primers for $H$ pylori to avoid amplification of non-specific bands owing to the presence of numerous DNAs other than $H$ pylori DNA;

- the use of a competitive template that is big enough not to overlap with primer dimers;

- thorough vortexing of sample suspensions before DNA preparation to make sure that $H$ pylori cells are distributed uniformly and so ensure that results are consistent and reproducible;

- a relatively large volume of specimen DNA should be taken for each PCR reaction.

Nevertheless, results are still less consistent and reliable if the numbers of $H$ pylori are below 10 cells per PCR reaction, although positive signals could be detected with as few as $1-5$ cells. This is in agreement with previous reports which showed that quantitation was less reliable when the target sequence was extremely small. ${ }^{17}{ }^{32}$ Quantitative cPCR is very time consuming and is not suitable for studying large samples. Therefore a generalised application of our results is not envisaged.

The method we describe seems extremely sensitive and specific and thus great care has to be taken to avoid sample contamination. We cannot completely exclude the possibility of low level contamination. However, the presence of $H$ pylori organisms in dental plaque samples seems to be independent of the presence of the organism in the stomach.

CONCLUSIONS

cPCR is useful for the quantitation of $H$ pylori in dental plaque. The number of the bacteria is very small and seems to be independent of infection in the stomach. H pylori may belong to the normal flora of the human oral cavity, maintaining a commensal relation with the host. The mere presence of the pathogen in the oral cavity does not appear to mean that an individual will develop the infection in the stomach. The number of $H$ pylori organisms necessary to induce infection and disease in the stomach is still unknown, and further studies are needed to investigate whether the presence of $H$ pylori in the mouth is transient and whether there are risk factors that favour its growth in the oral cavity.

1 Banatvala N, Lopez CR, Owen R, et al. Helicobacter pylori in dental plaque. Lancet 1993;341:380

2 D'Alessandro A, Seri S. Comparison of three different methods for evaluation of Helicobacter pylori (HP) in human dental plaque. Bolt Soc It Biol Sper 1992;68:769-73.

$3 \mathrm{Li} \mathrm{C}, \mathrm{Ha}$ T, Ferguson DA, et al. A newly developed PCR assay of $\mathrm{H}$. pylori in gastric biopsy, saliva, and feces. Evidences of high prevalence of $\mathrm{H}$. pylori in saliva supports oral transmission. Dig Dis Sci 1996;41:2142-9.

$4 \mathrm{Li} \mathrm{C}$, Musich PR, $\mathrm{Ha} \mathrm{T}$, et al. High prevalence of Helicobacter pylori in saliva demonstrated by a novel PCR Helicobacter pylori in saliva demon

5 Majmudar P, Shah SM, Dhunjibhoy KR, et al. Isolation of Majmudar P, Shah SM, Dhunjibhoy KR, et al. Isolation of
Helicobacter pylori from dental plaques in healthy volunteers. Indian $\mathcal{F}$ Gastroenterol 1990; 9:271-2.

6 Olsson K, Wadstrom T, Tyszkiewicz T. H. pylori in dental plaque. Lancet 1993;341:956-7.

7 Pytko-Polonczyk J, Konturek SJ, Karczewska E, et al. Oral cavity as permanent reservoir of Helicobacter pylori and potential source of reinfection. I Physiol Pharmacol 1996;47:121-9.

8 Song QS, Zheng ZT, Yu H. Helicobacter pylori in the dental plaque. Chin f Internal Med 1994;33:459-61.

9 Bernander S, Dalen J, Gastrin B, et al. Absence of Helicobacter pylori in dental plaque in Helicobacter pylori positive dyspeptic patients. Eur $\mathcal{F}$ Clin Microbiol Infect Dis 1993;12:282-5.

10 Bickley J, Owen RJ, Fraser AG, et al. Evaluation of the polymerase chain reaction for detecting the urease $\mathrm{C}$ gene of Helicobacter pylori in gastric biopsy samples and dental plaque. F Med Microbiol 1993;39:338-44.

11 Hardo PG, Tugnait A, Hassan F, et al. Helicobacter pylori infection and dental care. Gut 1995;37:44-6.

12 Luman W, Alkout AM, Blackwell CC, et al. Helicobacter pylori in the mouth - negative isolation from dental plaque and saliva. Eur f Gastroenterol Hepatol 1996; 8:11-14.

13 Gilliland G, Perrin S, Bunn HF. Competitive PCR for quantitation of mRNA. In: Innis MA, Gelfand DH, Sninsky J, eds. PCR protocols, a guide to methods and applications. San Diego: Academic Press, 1990:60-9.

14 Gilliland G, Perrin S, Blanchard K, et al. Analysis of cytokine mRNA and DNA: detection and quantitation by competitive polymerase chain reaction. Proc Natl Acad Sci USA 1990;87:2725-9.

15 Jalava T, Lehtovaara, Kallio A, et al. Quantification of hepatitis B virus DNA by competitive amplification and hybridization on microplates. BioTechniques 1993;15:134-

16 Menzo S, Bagnarelli P, Giacca M, et al. Absolute quantitation of viremia in human immunodeficiency virus infection by competitive reverse transcription and polymerase chain reaction. F Clin Microbiol 1992;30:1752-7.

17 Piatak M, Saag MS, Yang LC, et al. High levels of HIV-1 in plasma during all stages of infection determined by competitive PCR. Science 1993;259:1749-54.

18 Siebert PD, Larrick JW. PCR MIMICS: competitive DNA fragments for use as internal standards in quantitative PCR. BioTechniques 1993;14:244-9.

19 Furuta T, Kaneko E, Suzuki M, et al. Quantitative study of Helicobacter pylori in gastric mucus by competitive PCR using synthetic DNA fragments. 7 Clin Microbiol 1996;34: $2421-5$

20 Sambrook J, Fritsch EF, Maniatis T. Molecular cloning, a laboratory manual, 2nd ed. Cold Spring Harbor: Cold Spring Harbor Laboratory Press, 1989.

21 Roosendaal R, Kuipers EJ, van den Brule AJC, et al. Importance of the fiberoptic endoscope cleaning procedure for detection of $\mathrm{H}$ pylori infection in gastric biopsy by PCR. F Clin Microbiol 1994;32:1123-6.

22 Ellenrieder V, Glasbrenner B, Stoffels C, et al. Qualitative and semi-quantitative value of a modified 13C-urea breath test for identification of Helicobacter pylori infection. Eur $\mathcal{F}$ Gastroenterol Hepatol 1997;9:1085-9.

23 Kwork S, Higuchi R. Avoiding false positive with PCR. Nature 1989;339:539-47.

24 Tomb JF, White O, Kerlavage AR, et al. The complete genome sequence of the gastric pathogen Helicobacter pylori. Nature 1997;388:539-47.

25 Cammarota G, Tursi A, Montalto M, et al. Role of dental plaque in the transmission of Helicobacter pylori infection. f Clin Gastroenterol 1996;22:174-7.

26 Mapstone NP, Lynch DAF, Lewis FA, et al. Identification of Helicobacter pylori DNA in the mouths and stomachs of patients with gastritis using PCR. F Clin Pathol 1993;46: 540-3.

27 Clayton CL, Kleanthous H, Coates PJ, et al. Sensitive detection of Helicobacter pylori by using polymerase chain reaction. F Clin Microbiol 1992;30:192-200.

28 Hammar M, Tyszkiewicz T, Wadström T, et al. Rapid detection of Helicobacter pylori in gastric biopsy material by polymerase chain reaction. f Clin Microbiol 1992;30:54-8. 
29 Thoreson ACE, Borre MB, Andersen LP, et al. Development of a PCR-based technique for detection of Helicobacter pylori. FEMS Immunol Med Microbiol 1995;10:325-

Li C, Ferguson DA, Ha T, et al. A highly specific and sensitive DNA probe derived from chromosomal DNA of Helicobacter pylori is useful for typing $\mathrm{H}$. pylori isolates. $\mathcal{F}$ Clin Microbiol 1993;31:2157-62.
31 Song Q, Haller B, Schmid RM,et al. Helicobacter pylori in dental plaque. A comparison of different PCR primer sets. Dig Dis Sci 1999;44:479—84.

32 Becker-Andre M, Hahlbrock K. Absolute mRNA quantification using the polymerase chain reaction (PCR). A novel approach by a PCR aided transcript titration assay (PATTY). Nucleic Acids Res 1989;17:9437-46.

\section{Fournal of Clinical Pathology - http://www.jclinpath.com}

Visitors to the world wide web can now access the fournal of Clinical Pathology either through the BMJ Publishing Group's home page (http://www.bmjpg.com) or directly by using its individual URL (http://www.jclinpath.com). There they will find the following:

- Current contents list for the journal

- Contents lists of previous issues

- Members of the editorial board

- Information for subscribers

- Instructions for authors

- Details of reprint services

- Instructions for use of Pathology Interactive.

A hotlink gives access to:

- BMJ Publishing Group home page

- British Medical Association web site

- Online books catalogue

- BMJ Publishing Group books.

The web site is at a preliminary stage and there are plans to develop it into a more sophisticated site. Suggestions from visitors about features they would like to see are welcomed. They can be left via the opening page of the BMJ Publishing Group site or, alternatively, via the journal page, through "about this site". 